\title{
Sarbanes-Oxley And Dodd Frank: Then There Was Fraud
}

Dahli Gray, Keiser University, USA

Clemense Ehoff Jr., Central Washington University, USA

\begin{abstract}
The Sarbanes Oxley Act of 2002 and the Dodd Frank Act of 2010 are reviewed relative to the results of exploring selected fraud cases discovered in the years 2010 through 2013. These cases reflect that fraud continues to be discovered despite legislated efforts regarding financial fraud. The Dodd-Frank Wall Street Reform and Consumer Protection Act of 2010 responded to continued emergence of financial fraud cases in the years after the legislation of the Sarbanes Oxley Act of 2002. Assuming that implementation of Sarbanes Oxley Act of 2002 would take some time to decrease financial fraud, such cases discovered in the first seven years after the Sarbanes Oxley Act of 2002 were not included in this study. The conclusion and recommendation are that both additional legislation and better enforcement of existing legislation are needed.
\end{abstract}

Keywords: Financial Accounting; Fraud, Forensic Accounting; Sarbanes Oxley Act; Internal Control; Dodd-Frank Act

\section{INTRODUCTION}

Qf

elected financial accounting fraud cases discovered in the years 2010 through 2013 are explored to consider the effectiveness of the anti-fraud legislation passed in 2002 and 2010. The full title of the Sarbanes Oxley Act of 2002 is "An Act to protect investors by improving the accuracy and reliability of corporate disclosures made pursuant to the securities laws, and for other purposes." The full title of the Dodd-Frank Wall Street Reform and Consumer Protection Act of 2010 is "An Act to promote the financial stability of the United States by improving accountability and transparency in the financial system, to end 'too big to fail,' to protect the American taxpayer by ending bailouts, to protect consumers from abusive financial services practices, and for other purposes." The legislation of the Dodd Frank Act (2010) indicates that the Sarbanes Oxley Act was not enough. The legislation is summarized followed by the results of the research completed for this article. The cases summarized support the conclusion that more legislation and stricter enforcement of existing legislation are needed.

\section{Sarbanes-Oxley Act of 2002}

In the late 1990s and early 2000s, corporate scandals seemed to dominate business news. Global Crossing Ltd., Adelphia, WorldCom, AOL Time Warner, Tyco, Xerox and others were instrumental in crafting a "picture" of Corporate America filled with greed and somewhat immune from the principles of right and wrong. Perhaps the most memorable of these companies was the Enron Corporation. On the way down, it took out Arthur Andersen (one of the world's top public accounting firms at the time). Further, the Enron Corporation was the primary inspiration for the Sarbanes-Oxley Act (SOX, 2002).

The SOX (2002) was a government action aimed at restoring public confidence in financial information. The SOX contains twelve Titles aimed at strengthening corporate accountability and public accounting responsibilities. Title I established the Public Company Accounting Oversight Board (PCAOB). The PCAOB was and is appointed by the Securities and Exchange Commission (SEC). The PCAOB has the responsibility of (1) registering public accounting firms that prepare audit reports, (2) establishing auditing, ethics, independence and other regulatory rules and audit standards, (3) conducting inspections, investigations, and disciplinary proceedings, and (4) imposing sanctions (SOX). 
Title II focused on auditor independence (SOX, 2002). Three changes were outlined in this title. First, primary audit engagement partners must rotate off the engagement at least every five years. Second, registered accounting firms can't audit clients with a Chief Executive Officer (CEO), Chief Financial Officer (CFO), controller, or chief accountant who was employed by the accounting firm during the one-year period preceding the audit. The third change narrowed the scope of services that accounting firms provide to clients. Accounting firms are prohibited from providing consulting services to their audit clients, while tax services for audit clients were still allowed (SOX. 2002).

Title III addressed corporate responsibilities (SOX, 2002) including audit committee establishment and responsibilities. The CEO and CFO must sign financial reports filed with the SEC, certifying that the reports fairly present the financial condition and results of operation plus are free of material misstatements. Further, they are responsible for and are required to establish and maintain effective internal controls (SOX, 2002). Title IV enhanced financial disclosures. Annual reports must include an assessment by the CEO and CFO of the organization's internal controls. And the audit firm must attest to and issue a report on management's assessment (SOX, 2002). The remaining Titles described corporate responsibilities, accountability, and civil and criminal penalties (SOX, 2002). The Dodd-Frank Act is summarized next.

\section{Dodd-Frank Act of 2010}

In 2010, Congress passed, and President Obama signed, the Dodd-Frank legislation. This legislation established regulation of financial markets, hopefully avoiding another financial crisis similar to what happened in 2008. Following is a brief summary of the Dodd Frank (2010).

The Consumer Financial Protection Bureau oversees credit cards, credit fees, consumer loans, and mortgage underwriting functions (Dodd Frank, 2010). Banks must verify a borrower's job status, income and credit history. Second, the Financial Stability Oversight Council focusses on overall financial industry risk. Should a company appear "too big to fail", the company must be regulated by the Federal Reserve with increased reserve requirements. The Volker Rule prohibits banks from using or owning hedge funds for the banks' own profit. Credit default swaps and other risky derivatives are regulated by the SEC or the Commodities Futures Trading Commission. Hedge funds must register with the SEC, allowing the SEC to assess overall market risk. The Office of Credit Ratings regulates credit rating agencies such as Standard \& Poor's and Moody's. The Federal Insurance Office identifies insurance companies that present significant risks to the entire system. The Government Accountability Office must review future emergency loans, verifying that Treasury Department approval was acquired before making emergency loans to a single entity. The names of banks that receive these loans must be made public.

The SOX and the Dodd-Frank were government reactions to financial crises. The Acts indicated that the amount of self-regulation and/or ethical behavior exercised by the business community and the accounting profession was insufficient. Government intervention is a signal that ethical behavior was deemed insufficient. The question that remains is whether these two Acts have provided a sufficient replacement for the lack of ethical behavior. The answer appears to be a resounding "No" as indicated by the following sections using selected fraud cases.

\section{Cases}

Thirty fraud cases were selected and are listed in Table 1, along with the year in which the fraud was discovered. Eight cases were discovered in 2013, 11 in 2012, seven in 2011, and four in 2010. The year of discovery was used to organize the reported results. The year that the fraud began is not easily identified and often is not in reports (e.g., news releases). This research focused on financial accounting, not other types of fraud (e.g., tax accounting fraud, occupational fraud). However, the categories overlap and each impacts financial reports in different ways. The Internal Revenue Service (IRS, 2013) reports tax fraud cases, which can be found on the IRS website, and the Association of Certified Fraud Examiners (ACFE, 2012) has completed six studies of occupational fraud. The most recent report addressed occupational fraud from January 2011 through December 2012 and documents that the discovery of occupational fraud continues to grow. Marquet International (2013) reported that 
528 embezzlement cases were discovered in 2012, which was the highest number for the past five years, representing an increase of more than 11 percent over 2011. This report further documented that the SOX and Dodd Frank Acts did not result in a decrease in discovered fraud. The selected fraud cases for this study are briefly summarized next.

Table 1: Financial Accounting Fraud Cases

\begin{tabular}{|c|c|}
\hline Organization & Year Fraud Discovered \\
\hline $\mathrm{A} 4 \mathrm{e}$ & 2012 \\
\hline Adobe & 2012 \\
\hline Angel Food Ministries & 2011 \\
\hline ATM Scheme & 2013 \\
\hline Baierl Acura & 2011 \\
\hline Bank of America & 2012 \\
\hline Bitcoin & 2013 \\
\hline Carolina Revenue Dept. & 2012 \\
\hline Citicorp & 2011 \\
\hline Dwelling House Savings \& Loans & 2012 \\
\hline Fannie Mae & 2011 \\
\hline Groupon & 2012 \\
\hline HSBC & 2013 \\
\hline JP Morgan & 2010 \\
\hline Kennesaw State University & 2012 \\
\hline Koss & 2010 \\
\hline Latex International & 2012 \\
\hline LocatePlus, Inc. & 2010 \\
\hline New House, LLC & 2011 \\
\hline Ocwen & 2013 \\
\hline Olympus & 2011 \\
\hline Quest & 2010 \\
\hline Small Business Administration & 2013 \\
\hline Sony & 2011 \\
\hline Target & 2013 \\
\hline Tribune Co. & 2012 \\
\hline Wal-Mart & 2013 \\
\hline Wheaton Franciscan Healthcare & 2013 \\
\hline Woodruff Arts Center & 2012 \\
\hline Zappo & 2012 \\
\hline
\end{tabular}

\section{Cases Discovered in 2010}

This section briefly explores the cases of JP Morgan, Koss, LocatePlus, and Quest, which illustrates how fraud might only result in the loss of a job. As many people have experienced and survived the loss of a job, the financial benefits of committing fraud and losing a job versus merely losing a job without any financial benefits could motivate fraud behavior. The concept of "too big to fail" seemed to extend to no jail time or financial penalty for fraudsters at big organizations. The first organization presented next is a prime example.

JP Morgan fits in several years, including the year 2008, for fraud being discovered. "US office of the comptroller of the currency ... said its inquiries had found inadequate oversight and governance to protect the bank from material risk, inadequate risk management, inadequate control over pricing of trades, inadequate development and implementation of models used by the [JP Morgan] bank, and inadequate internal audit processes" (Rushe, 2013). Touryalai (2012) concluded that JP Morgan was the biggest banking scandal of 2012 with the penalty merely being that a couple of people lost their jobs. The lack of jail or prison time and/or monetary fines might have signaled other existing and potential fraudsters to continue committing fraud.

Koss (2011) Corporation's fraud was discovered in 2010 and was "materially inaccurate financial statements, book and records, and lack of adequate internal controls from fiscal years 2005 through 2009." SOX 
(2002) mandated adequate internal control. The Koss (2011) fraud was reported to have begun three years after the SOX law was passed, which indicates that the SOX either was not taken seriously or was flawed if taken seriously.

LocatePlus executives "were charged with securities fraud, false statements to company auditors, false statements to the United States (US) SEC, false certifications as the CEO and CFO of a publicly traded company, aggravated identity theft and engaging in unlawful financial transactions (Covey, 2010).

Quest Diagnostics fits in more than one year beginning with 2005 when a whistleblower reported fraud. Quest was accused of overbilling Medicare millions of dollars, but that "case was dismissed for technical reasons that had nothing to do with its merits" (Sharp, 2011). In another case, Quest denied “... all allegations in the complaint ... [and] it settled "to put the lawsuit behind us" (Lifsher, 2011). "California's biggest provider of medical lab services, accused of overcharging the state's medical care program for the poor and disabled, agrees to pay \$241 million in what is the largest settlement in the history of California's False Claims Act” (Lifsher, 2011).

The cases discovered in 2010 gave mixed signals as Quest Diagnostics agreed to pay a large settlement versus JP Morgan where there were merely a couple of people losing their jobs. A large settlement is not the same as serving jail time or paying a court imposed financial fine or penalty. The next section presents example cases that were discovered in 2011.

\section{Cases Discovered in 2011}

This section briefly explores Angel Food Ministries, Baierl Acura, Citicorp, Fannie Mae, New House, Olympus and Sony. Lack of adequate internal controls were blamed for much of the fraud. Internal controls, as required by SOX (2002), appear to either not work or not be adequately implemented.

Angel Food Ministries' entire accounting history had to be reviewed relative to the fraud allegations (Johnson, 2012), which indicated the significant role of accounting records.

The Baierl Acura Controller "embezzled more than $\$ 10$ million from her employer" (Baierl Acura, 2012a). Lack of adequate internal controls allowed this accounting fraud to occur (Baierl Acura, 2012b).

Citicorp "initiated internal fraud alerts" in response to discovering the 2011 data weakness (Schwartz \& Dash, 2011), which makes one wonder why the internal control procedures did not exist before the data breach. Section 404 of SOX, requiring improved internal control, was considered too expensive to implement. Data breaches, such as this one, seem to suggest that the SOX Section 404 requirement should have been - and should be - required.

Epstein (2011) reported that the "Citigroup hackers stole \$2.7 million" and that Citicorp reimbursed the account holders for their losses. Despite internal fraud alerts initiated in 2011, fraud continued as discovered in the year 2013 (Dunsmoor, 2013).

Fannie Mae executives committed fraud beginning in the year 2006, but were not charged with fraud until 2011 (Hilzenrath \& Goldfarb, 2011). This fraud was blamed for part of the housing debacle. New House employees confessed to fraud (Federal Bureau of Investigation New Haven Division, 2012); Sakr (2013) reported that the Olympus executives involved in the accounting fraud did not get any jail time; and Sony shut down Internet access after data was breached (Morris, 2011). The next section presents examples of fraud cases discovered in 2012.

\section{Cases Discovered in 2012}

This section briefly explores A4c, Adobe, Bank of America, Carolina Revenue Dept., Dwelling House Savings and Loans (DHSL), Groupon, Kennesaw State University, Latex International, Tribune Woodruff Arts Center and Zappo. 
Morrison and Merrick (2012) reported that the chairman of A4e committed fraud and Urquhart (2013) reported how several employees participated in the fraud. Adobe was criticized for lax security that resulted in data breach and fraud (Gilbert, 2012); Bank of America's lack of strong controls resulted in data breach (Booton, Egan \& Samson, (2012); Carolina Revenue Department suffered data breaches due to lax security (e.g., internal controls) (Brown, 2012); and Dwelling House Savings and Loans (DHSL) was the victim of bank fraud and money laundering (Mandak, 2012).

Groupon's accounting scandal was revealed a few months after the IPO was issued (Pavlo, 2012); Kennesaw State University personnel used shell organizations to commit fraud (Tdemel, 2013); and Latex International executive exploited weak internal controls to commit fraud (Cleary, 2012). Tribune employee diverted real estate commissions to herself (Channick, 2012); Woodruff Arts Center's weak internal controls resulted in an employee setting up a fake organization and transferring funds to it (Suggs, 2012); and Zappo experienced data breach due to lack of adequate internal controls (Lennon, 2012). The next section presents a sample of fraud cases discovered in 2013.

\section{Cases Discovered in 2013}

This section illustrates how internal controls are not yet adequate to deter fraud activities using ATM Scheme, Bitcoin, HSBC, Ocwen, Small Business Administration, Target, Wal-Mart, and Wheaton Franciscan Healthcare as examples. The ATM Scheme "thefts underscored the vulnerability of financial institutions around the world to clever criminals working to stay a step ahead of the latest technologies designed to thwart them" (Santora, (2013). Popper (2013) reported that Bitcoin was a "virtual commodity that does not share the same legal status of a currency." In the United States, that classification could put Bitcoin under the Commodity Futures Trading Commission, but that agency has not assumed responsibility. In the immediate future, the most likely source of enforcement may be the Federal Bureau of Investigation's cyber-security team.

HSBC Mortgage Services, Incorporated and HSBC Bank were victims of fraud due to lack of adequate internal controls regarding gift cards (USDOJ, 2013a); Ocwen employees defrauded the US Veterans Affairs (USDOJ. 2013b); and the Small Business Administration was defrauded by Jade Capital and Investments (USAO, 2013). "The Target breach, from November to December 15, is officially the second largest breach of a retailer in history. The biggest was a 2005 breach at TJ Maxx that compromised records for 90 million customers" (Perlroth, 2013). A Wal-Mart employee was able to cash fraudulent checks and coupons, plus return items that she had not purchased (LeFlore, 2013). Wheaton Franciscan Healthcare was defrauded by a payroll specialist (Spoto, 2013).

The fraud cases discovered in 2013 further illustrate that fraud extends across industries (e.g., retail. Healthcare, financial intermediaries) and continues to be very large. Cyber-fraud appears to be growing as technology provides more opportunities to commit the crime from a distance. The fraud problem should be viewed as an opportunity for forensic accountants and auditors to extend and develop expertise to prevent, identify and resolve these situations.

\section{SUMMARY}

Fraud cases have been studied for decades and despite laws prohibiting fraud, it continues and appears to be increasing. Perhaps the legislation has improved the discovery process so that it merely appears that fraud activity has grown and is growing. Improved internal control systems, plus support for whistleblowers, may explain the continued and possibly increasing discovery of financial fraud. A question that remains unanswered is whether there is actually more fraud activity or is there just more discovery of fraud activities. What is clear is that fraud is evolving and exploiting technology (e.g., Internet systems locally, regionally, nationally and globally) and technology advances continue to change the process of financial fraud. Cyber-crime discovered toward the end of 2013 regarding the Target Corporation emphasizes the impact of advances in technology resulting in data breaches that extend beyond borders (Perlroth, 2013). Both additional legislation and better enforcement of existing legislation are needed to address the continuing fraud that appears to expand with evolving technology, along with classic fraud schemes (e.g., payroll) continuing to be initiated and discovered. 


\section{AUTHOR INFORMATION}

Dr. Dahli Gray, CPA, CMA, CFE, CGMA, is an Accounting Professor at Keiser University. She earned her doctoral degree from the George Washington University. She has over 40 journal articles, including articles in journals such as the Journal of Accounting Research and the Journal of Accountancy. She has made over 60 professional presentations including at American Accounting Association meetings plus at other conferences in the United States and other countries such as Japan and Ireland. Dr. Gray has been tenure-track faculty at universities such as the University of Notre Dame and the American University. She has a consulting practice. Email: DGray@KeiserUniversity.edu

Dr. Clemense Ehoff Jr., CPA, CGMA, is an Assistant Accounting Professor, Central Washington University, Ellensburg, Washington. He holds a Ph. D in Business Administration from San Francisco's Golden Gate University. He has more than 30 years professional business experience and has held full-time faculty and adjunct positions at universities predominantly in the Eastern United States. Over the last ten years, Dr. Ehoff has been involved in teaching accounting and tax courses in an online platform as well as in the face-to-face classroom. He operates a consulting and tax practice. He has published articles in Elevator World, and other journals. Email: drehoff@comcast.net

\section{REFERENCES}

1. Association of Certified Fraud Examiners (ACFE). (2012). Report to the Nation. ACFE. Retrieved from http://www.acfe.com/RTTN/ .

2. Baierl Acura. (2012a). Former Baierl Acura Controller Admits Embezzling \$10.2 Million. U.S. Attorney's Office. Federal Bureau of Investigation, Pittsburg. Retrieved from http://www.fbi.gov/pittsburgh/pressreleases/2012/former-baierl-acura-controller-admits-embezzling-10.2-million

3. Baierl Acura. (2012b). Woman embezzles $\$ 10$ million in Baierl Acura fraud. Prosecutors say Patricia Smith funded extravagant lifestyle with money from Pine Township car dealership. WTAE.com. Retrieved from http://www.wtae.com/news/local/allegheny/Woman-embezzles-10-million-in-Baierl-Acura-fraud//10927008/12721358/-/2otbig/-/index.html

4. $\quad$ Booton, J., Egan M. \& Samson A. (2012, September 18). Bank of America Hit by Cyber Attack. Fox News. Retrieved from http://www.foxbusiness.com/industries/2012/09/18/bank-america-websiteexperiencing-sporadic-outages/.

5. Brown, R. (2012, November 20). South Carolina Offers Details of Data Theft and Warns It Could Happen Elsewhere. New York Times. Retrieved from http://www.nytimes.com/2012/11/21/us/more-details-ofsouth-carolina-hacking-episode.html?_r=0 .

6. Cleary, T. (2012, July 11). Ex-CEO gets 70 months for fraud, tax evasion. Connecticut Post. Retrieved from http://www.ctpost.com/news/article/Ex-CEO-gets-70-months-for-fraud-tax-evasion-3697276.php

7. Channick, R. (2012, December 28). Former Tribune Co. exec charged with defrauding company. Chicago Tribune News. Retrieved from www.chicagotribunenews.com: http://articles.chicagotribune.com/2012-1228/news/ct-met-former-tribune-executive-indicted-1228-20121228_1_real-estate-stephanie-paterindictment

8. Convey, E. (2010, November 11). Former LocatePlus execs charged with securities fraud. Boston Business Journal . Retrieved from http://www.bizjournals.com/boston/blog/mass-high-tech/2010/11/formerlocateplus-execs-charged-with.html

9. Dodd-Frank Wall Street Reform and Consumer Protection Act (Dodd Frank). (2010). An Act to promote the financial stability of the United States by improving accountability and transparency in the financial system, to end "too big to fail", to protect the American taxpayer by ending bailouts, to protect consumers from abusive financial services practices, and for other purposes (Dodd-Frank Wall Street Reform and Consumer Protection Act). Government Printing Office. Retrieved from http://www.gpo.gov/fdsys/pkg/PLAW-111publ203/pdf/PLAW-111publ203.pdf

10. Dunsmoor, B. (2013, August 21). Former Citibank Employee Charged with Bank Fraud. Keloland.com . JBER set up page.docx Retrieved from http://www.keloland.com/newsdetail.cfm/former-citibankemployee-charged-with-bank-fraud/?id=152226 
11. Epstein, Z. (2011, June 27). Citigroup hackers stole $\$ 2.7$ million in recent breach. BRG.com. Retrieved from http://bgr.com/2011/06/27/citigroup-hackers-stole-2-7-million-in-recent-breach/

12. Federal Bureau of Investigation New Haven Division. (2012, March 29). Woman Who Orchestrated $\$ 6$ Million Embezzlement Scheme Sentenced to More Than Eight Years in Prison [Press release.] Federal Bureau of Investigation New Haven Division. Retrieved from http://www.fbi.gov/newhaven/pressreleases/2012/woman-who-orchestrated-6-million-embezzlement-scheme-sentenced-to-more-than-eightyears-in-prison

13. Gilbert, D. (2012, November 16). Adobe Password Security Criticised by Experts. International Business Times. Retrieved from http://www.ibtimes.co.uk/articles/405706/20121116/adobe-data-breach-confirmedsecurity-criticised.htm

14. Hilzenrath, D. \& Goldfarb, Z. (2011, December 16). SEC charges former Fannie Mae, Freddie Mac executives with fraud. Washington post. Retrieved from http://articles.washingtonpost.com/2011-1216/business/35285965 1 freddie-mac-executives-sec-charges-daniel-h-mudd.

15. Internal Revenue Service (IRS). (2013). Examples of corporate fraud investigations fiscal year 2013. IRS. Retrieved from http://www.irs.gov/uac/Examples-of-Corporate-Fraud-Investigations-Fiscal-Year-2013

16. Johnson, J. (2012, December 1). Angel Food Ministry racketeering bogged down by million pages of documents. OnlineAthens Banner-Herald. Retrieved from http://onlineathens.com/local-news/2012-1201/angel-food-ministry-racketeering-case-bogged-down-millions-pages-documents

17. Koss Corporation (Koss). (2011, October 24). Securities and Exchange Commission (SEC) versus Koss Corporation and Michael J. Koss, Civil Case No. 2:11-cv-00991, USDC, E.D., Wisconsin. United States SEC. Retrieved from http://www.sec.gov/litigation/litreleases/2011//r22138.htm

18. LeFlore, J. (2013, May 28). Embezzlement at Wal-Mart. McAlester News-Capital. Retrieved from http://www.mcalesternews.com/x1167598479/Embezzlement-at-Walmart

19. Lennon, M. (2012, January 15). Zappos Hacked: Internal Systems Breached in Cyber Attack. Security Week. Retrieved from http://www.securityweek.com/zappos-hacked-says-internal-systems-breached-cyberattack

20. Lifsher, M. (2011, May 20). Quest Diagnostics settles Medi-Cal whistle-blower suit. Los Angeles Times. Retrieved from http://articles.latimes.com/2011/may/20/business/la-fi-quest-settlement-20110520

21. Mandak, J. (2012, January 4). Woman gets $12 \frac{1}{2}$ years for Pittsburgh thrift fraud. Associated Press York Daily Record/Sunday News. Retrieved from http://www.ydr.com/rss/ci_19674207?source=rss

22. Marquet International. (2013). The 2012 Marquet report on embezzlement. Marquet International. Retrieved from http://www.marquetinternational.com/pdf/the 2012_marquet report_on_embezzlement.pdf

23. Morris, C. (2011, April 25). Hackers Take Down Sony’s PlayStation Network. Retrieved from http://www.cnbc.com/id/42750388

24. Morrison, S. \& Merrick, J. (2012). Exclusive: A4e and a 200m back-to-work scandal. The Independent. Retrieved from http://www.independent.co.uk/news/uk/crime/exclusive-a4e-and-a-200m-backtoworkscandal-7440966.html?printServic

25. Pavlo, W. (2012, April 3). Groupon accounting scandal, and we're surprised? Forbes. Retrieved from JBER set up page.docx http://www.forbes.com/sites/walterpavlo/2012/04/03/groupon-accounting-scandaland-were-surprised/

26. Perlroth, N. (2013, December 27). Target's Nightmare Goes On: Encrypted PIN Data Stolen. New York Times. Retrieved from http://bits.blogs.nytimes.com/2013/12/27/targets-nightmare-goes-on-encrypted-pindata-stolen/?hpw\&rref=technology\&_r=0

27. Popper, N. (2013, December 6). In the Murky World of Bitcoin, Fraud is Quicker than the Law. New York Times. Retrieved from http://www.cnbc.com/id/101252210

28. Rushe, D. (2013, September19). London Whale scandal to cost JPMorgan $\$ 920 \mathrm{~m}$ in penalties. The Guardian. Retrieved from http://www.theguardian.com/business/2013/sep/19/jp-morgan-920m-fine-london-whale

29. Sakr, S. (2013, July 3). No jail time for Olympus bosses who committed $\$ 1.7$ billion accounting fraud . Engadget. Retrieved from http://www.engadget.com/2013/07/03/olympus-chairman-and-others-sentenced

30. Santora, M. (2013, May 10). In Hours, Thieves Took \$45 Million in A.T.M. Scheme. New York Times. Retrieved from http://www.nytimes.com/2013/05/10/nyregion/eight-charged-in-45-million-global-cyberbank-thefts.html?_r=0 
31. Sarbanes Oxley Act (SOX). (2002, July 30). Public Law 107-204: An Act to protect investors by improving the accuracy and reliability of corporate disclosures made pursuant to the securities laws, and for other purposes. SEC. Retrieved from http://www.sec.gov/about/laws/soa2002.pdf

32. Schwartz, N. \& Dash, E. (2011, June 13). Thieves Found Citigroup Site an Easy Entry. NewYork Times. Retrieved from http://www.nytimes.com/2011/06/14/technology/14security.html?pagewanted=all\&_r=0

33. Sharp, K. (2011, September). To Save on Health Care, First Crack Down on Fraud. New York Times. Retrieved from http://www.nytimes.com/2011/09/27/opinion/to-save-on-health-care-first-crack-down-onfraud.html

34. Spoto, C. (2013, August 1). \$1 Million Payroll Scheme Reported at Wheaton Franciscan. The Journal Times. Retrieved from http://journaltimes.com/news/payroll-theft-reported-at-wheatonfranciscan/article 4c53b3a4-fae2-11e2-a424-0019bb2963f4.html?cid=print.

35. Suggs, E. (2012, December 23). Weeks later, still no arrests in Woodruff Arts Center scam. Atlanta Journal-Constitution. Retrieved from http://www.ajc.com/news/news/local/weeks-later-still-no-arrests-inwoodruff-arts-cent/nTc4w/

36. Tdemel. (2013, March 28). Former University Employee Arrested in Connection with Fraud Case: News at $K S U$. Retrieved from: http://web.kennesaw.edu/news/print/29458

37. Touryalai, H. (2012, December 27). 10 Biggest Banking Scandals of 2012. Forbes. Retrieved from http://www.forbes.com/sites/halahtouryalai/2012/12/27/10-biggest-banking-scandals-of-2012/

38. United States (US) Attorney's Office (USAO). (2013, March 19). Loan Broker Pleads Guilty in Conspiracy to Fraudulently Obtain More Than \$100 Million in Small Business Administration-Backed Loans.

Retrieved from Federal Bureau of Investigation : http://www.fbi.gov/baltimore/press-releases/2013/loanbroker-pleads-guilty-in-conspiracy-to-fraudulently-obtain-more-than-100-million-in-small-businessadministration-backed-loans

39. United States Department of Justice (USDOJ). (2013a). Husband And Wife Sentenced To Prison For Defrauding HSBC Mortgage Services And Bank Out Of More Than \$2Million. United States Department of Justice Middle District of Florida. Retrieved from http://www.justice.gov/usao/flm/press/2013/june/20130619_Guy.html

40. USDOJ. (2013b). Former Employee of Florida Property Management Company Sentenced to serve Time in Prison for Wire Fraud. USDJ. Retrieved from http://www.justice.gov/opa/pr/2013/September/13-at1098.html.

41. Urquhart, C. (2013, September 26). Nine A4e employees charged with fraud. The Guardian. Retrieved from http:// www.theguardian.com/uk-news/2013/sep/26/a4e-employees-fraud-charge 